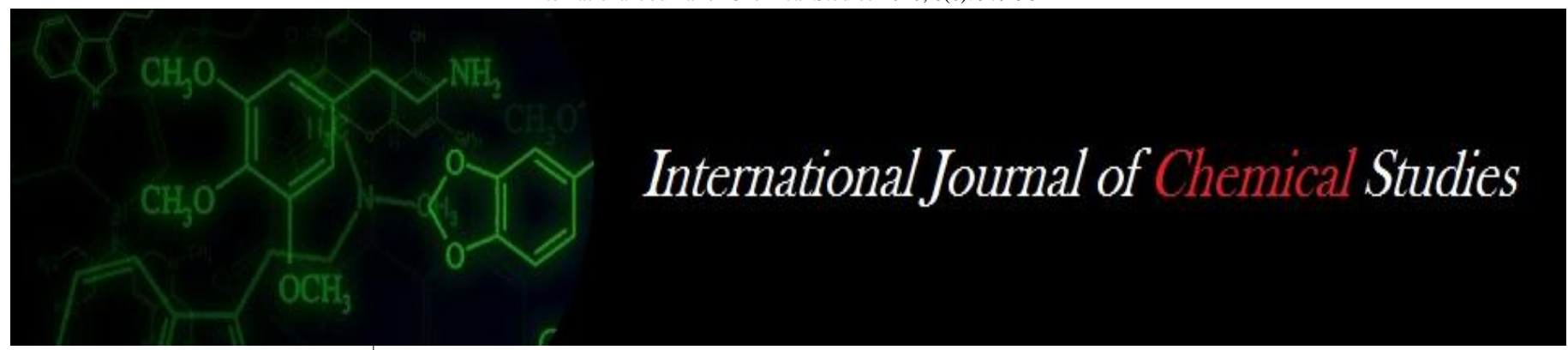

P-ISSN: 2349-8528

E-ISSN: 2321-4902

www.chemijournal.com

IJCS 2020; 8(6): 979-982

(C) 2020 IJCS

Received: 12-09-2020

Accepted: 24-10-2020

\section{Logesh Kumar S}

PG Scholar, Department of

Agronomy, Agricultural College

\& Research Institute,

Killikulam, Tamil Nadu

Agricultural University,

Thoothukudi, Tamil Nadu, India

VM Sankaran

Professor and Head, Department

of Agronomy, Agricultural

College \& Research Institute,

Killikulam, Tamil Nadu

Agricultural University,

Thoothukudi, Tamil Nadu, India

\section{Hemalatha}

Associate Professor, Department

of Agronomy, Agricultural

College \& Research Institute,

Killikulam, Tamil Nadu

Agricultural University,

Thoothukudi, Tamil Nadu, India

S Suresh

Professor and Head, Department of Soil Science and Agricultural Chemistry, Agricultural College

\& Research Institute,

Killikulam, Tamil Nadu

Agricultural University,

Thoothukudi, Tamil Nadu, India

Corresponding Author:

Logesh Kumar S

PG Scholar, Department of

Agronomy, Agricultural College

\& Research Institute,

Killikulam, Tamil Nadu

Agricultural University,

Thoothukudi, Tamil Nadu, India

\section{Effect of different level of fertilizers and foliar nutrition on yield attributes and yield of Pearl millet under rainfed condition}

\author{
Logesh Kumar S, VM Sankaran, M Hemalatha and S Suresh
}

DOI: https://doi.org/10.22271/chemi.2020.v8.i6n.10893

\begin{abstract}
A field experiment was laid out in randomised block design with three replications during rabi season of 2019 at Agricultural College and Research Institute, Killikulam (Tamil Nadu) to study the effect of different level of fertilizers and foliar nutrition on yield attributes and yield of pearl millet under rainfed condition. The investigation was comprised of 13 treatments with different levels and foliar application of fertilizers. The study revealed that yield attributes and yield of pearl millet were significantly differed with treatments imposed. Among the various treatments, application of $125 \% \mathrm{RDF}+1 \%$ Urea $+1 \% \mathrm{KCl}$ $+0.5 \% \mathrm{ZnSO}_{4}+0.5 \% \mathrm{FeSO}_{4}$ had significantly recorded higher number of productive tillers plant ${ }^{-1}$ (2.68), earhead length $(27.3 \mathrm{~cm})$, earhead girth $(8.2 \mathrm{~cm})$, number of grains earhead ${ }^{-1}(2136)$, test weight $(15.46 \mathrm{~g})$, grain yield $\left(2692 \mathrm{~kg} \mathrm{ha}^{-1}\right)$ and straw yield $\left(4134 \mathrm{~kg} \mathrm{ha}^{-1}\right)$.
\end{abstract}

Keywords: Pearl millet, fertilizer levels, foliar nutrition, yield attributes, yield

\section{Introduction}

Pearl millet (Pennisetum glaucum L.) is one of the most important dryland crops which is predominantly grown in arid and semi-arid regions of the world. It is also known as bulrush millet, cattail millet or bajra. It is a dual purpose crop which is used for both grain and fodder purpose. In India, Pearl millet is grown in an area of $7.48 \mathrm{~m}$ ha with production of $9.2 \mathrm{mt}$ of grains and productivity of $1231 \mathrm{~kg} \mathrm{ha}^{-1}$. In Tamil Nadu, it has covered an area of $0.63 \mathrm{~L} \mathrm{ha}$ with the production of $1.43 \mathrm{~L} \mathrm{t}$ and $2277 \mathrm{~kg} \mathrm{ha}^{-1}$ of productivity (INDIASTAT 2018). Because of the increase in prices of cereals (Rice, Wheat, Maize), pearl millet has become the cheapest alternative source for non-food uses like cattle feed, poultry feed, alcohol and starch industries (Reddy et al., 2013) ${ }^{[11]}$.

Pearl millet is mostly grown as rainfed crop in low fertile soils which leads to poor nutrient uptake and produced low yield. Crop removes $72 \mathrm{~kg}$ of $\mathrm{N}, \mathrm{P}_{2} \mathrm{O}_{5}$ and $\mathrm{K}_{2} \mathrm{O} / \mathrm{ha} /$ annum while only 10-20 kg of them are supplied through fertilizers (Suresh et al., 2018) ${ }^{[16]}$. Therefore, application of major nutrients at basal in optimum dose is required to enhance the crop growth at early stages and improved crop yield. In rainfed areas, because of deficit moisture conditions root cannot absorb enough nutrients from soil to compensate requirements even when it is present in sufficient quantity. Foliar application of nutrients helps in meeting the requirement and improves the fertilizer use efficiency if soil application has failed. Foliar spraying of $\mathrm{N}, \mathrm{P}$ and $\mathrm{K}$ fertilizers was more effective and had positive effect in improving yield of the crop (Reddy et al., 2018) ${ }^{[12]}$. Indian soils are mostly deficient in zinc and deficiency causes disturbance in photosynthesis and nitrogen metabolism of plants. Iron is an important constituent of cytochromes, ferredoxin, catalase, peroxidase, ferrochrome and also for chlorophyll synthesis in plants. Foliar supplementation of zinc and iron had improved the grain quality, yield and higher economic production (Rani et al., 2017) ${ }^{[10]}$. Hence, present investigation was designed to study the optimum fertilizer dose and performance of foliar feeding in rainfed pearl millet.

\section{Materials and Methods}

A field investigation was conducted at Agricultural College and Research Institute, Killikulam, Tamil Nadu Agricultural University, Thoothukudi district of Tamil Nadu during Rabi 2019 to 
study the effect of different fertilizer levels and foliar nutrition on yield attributes and yield of rainfed pearl millet. The experiment was laid out in Randomized Block Design with three replication and thirteen treatments viz., $\mathrm{T}_{1}-75 \%$ $\mathrm{RDF}+$ Foliar application $1 \%$ Urea $+1 \% \mathrm{KCl}, \mathrm{T}_{2}-100 \% \mathrm{RDF}$ + Foliar application $1 \%$ Urea $+1 \% \mathrm{KCl}, \mathrm{T}_{3}-125 \% \mathrm{RDF}+$ Foliar application $1 \%$ Urea $+1 \% \mathrm{KCl}, \mathrm{T}_{4}-75 \% \mathrm{RDF}+$ Foliar application $1 \%$ Urea $+1 \% \mathrm{KCl}+0.5 \% \mathrm{ZnSO}_{4}+0.5 \% \mathrm{FeSO}_{4}$, $\mathrm{T}_{5}-100 \% \mathrm{RDF}+$ Foliar application $1 \%$ Urea $+1 \% \mathrm{KCl}+$ $0.5 \% \mathrm{ZnSO}_{4}+0.5 \% \mathrm{FeSO}_{4}, \mathrm{~T}_{6}-125 \% \mathrm{RDF}+$ Foliar application $1 \%$ Urea $+1 \% \mathrm{KCl}+0.5 \% \mathrm{ZnSO}_{4}+0.5 \% \mathrm{FeSO}_{4}$, $\mathrm{T}_{7}-75 \% \mathrm{RDF}+$ Foliar application $1 \%$ Polyfeed, $\mathrm{T}_{8}-100 \%$ $\mathrm{RDF}+$ Foliar application $1 \%$ Polyfeed, $\mathrm{T}_{9}-125 \% \mathrm{RDF}+$ Foliar application $1 \%$ Polyfeed, $\mathrm{T}_{10}-75 \% \mathrm{RDF}+$ Foliar application $1 \%$ Polyfeed $+0.5 \% \mathrm{ZnSO}_{4}+0.5 \% \mathrm{FeSO}_{4}, \mathrm{~T}_{11}-$ $100 \% \mathrm{RDF}+$ Foliar application $1 \%$ Polyfeed $+0.5 \% \mathrm{ZnSO}_{4}+$ $0.5 \% \mathrm{FeSO}_{4}, \mathrm{~T}_{12}-125 \% \mathrm{RDF}+$ Foliar application $1 \%$ Polyfeed $+0.5 \% \mathrm{ZnSO}_{4}+0.5 \% \mathrm{FeSO}_{4}, \mathrm{~T}_{13}-$ Absolute Control. Pearl millet hybrid TNAU Cumbu Hybrid Co-9 was sown with seed rate of $5 \mathrm{~kg} \mathrm{ha}^{-1}$ and with a spacing of $45 \times 15$ $\mathrm{cm}$. The entire dose of fertilizers was applied as basal as per the treatment schedule. For foliar application $1 \%$ of Urea, Kcl and Polyfeed (19:19:19) and 0.5\% of zinc and iron sulphate were prepared and applied at 20 and 40 days after sowing of the crop as per the treatment schedule. Five plants from each treatmental plot were selected randomly, tagged for taking observations viz., number of productive tillers plant ${ }^{-1}$, earhead length, earhead girth, number of grains earhead ${ }^{-1}$, test weight, grain yield and straw yield. Data was collected and analysed statistically with procedure described by Gomez and Gomez (1984) ${ }^{[3]}$. Critical differences were worked at $5 \%$ probability level and significant differences among treatments were determined.

\section{Results and Discussion \\ Effect on yield attributes}

Yield attributing characters in rainfed pearl millet were found to be significantly influenced by application of different fertilizer levels and foliar nutrient spray (Table 1).

\section{Number of productive tillers plant ${ }^{-1}$}

Significantly higher number of productive tillers plant ${ }^{-1}(2.68)$ was recorded with application of $125 \% \mathrm{RDF}+1 \%$ Urea $+1 \%$ $\mathrm{KCl}+0.5 \% \mathrm{ZnSO}_{4}+0.5 \% \mathrm{FeSO}_{4}\left(\mathrm{~T}_{6}\right)$ than other treatments and the result was in similarity with Rani et al., (2017) ${ }^{[10]}$ who observed higher number of productive tillers plant ${ }^{-1}$ with $150 \% \mathrm{RDF}+0.5 \% \mathrm{ZnSO}_{4}+0.2 \% \mathrm{FeSO}_{4}$ foliar spray. It was statistically on par with $100 \% \mathrm{RDF}+1 \%$ Urea $+1 \% \mathrm{KCl}+$ $0.5 \% \mathrm{ZnSO}_{4}+0.5 \% \mathrm{FeSO}_{4}\left(\mathrm{~T}_{5}\right)$ which recorded 2.56, while lowest number of productive tillers plant ${ }^{-1}$ (1.72) was found with absolute control (Table 1). The increase in number of tillers might be due to application of high amount of potassium, phosphorus and nitrogen in $125 \%$ RDF which promoted strong cell wall development and resulted in stiffer straw and produced more number of tillers as compared to control as reported by Joshi et al., (2018) ${ }^{[4]}$ and Singh et al., $(2017)^{[14]}$.

Table 1: Effect of fertilizer levels and foliar nutrition on yield attributes of rainfed Pearl millet

\begin{tabular}{|c|c|c|c|c|c|}
\hline \multicolumn{2}{|r|}{ Treatments } & \multirow{2}{*}{$\begin{array}{c}\begin{array}{c}\text { Productive } \\
\text { tillers plant }\end{array} \mathbf{t}^{\mathbf{1}} \\
1.94 \\
\end{array}$} & \multirow{2}{*}{$\begin{array}{c}\begin{array}{c}\text { Earhead } \\
\text { length }(\mathbf{c m})\end{array} \\
18.8 \\
\end{array}$} & \multirow{2}{*}{$\begin{array}{c}\begin{array}{c}\text { Earhead } \\
\text { girth }(\mathbf{c m})\end{array} \\
5.6 \\
\end{array}$} & \multirow{2}{*}{$\begin{array}{c}\begin{array}{c}\text { No. of grains } \\
\text { earhead }^{-1}\end{array} \\
1658 \\
\end{array}$} \\
\hline $\mathrm{T}_{1}$ & $75 \% \mathrm{RDF}+1 \%$ Urea $+1 \% \mathrm{KCl} \mathrm{FS}$ at $20 \& 40 \mathrm{DAS}$ & & & & \\
\hline $\mathrm{T}_{2}$ & $100 \% \mathrm{RDF}+1 \%$ Urea $+1 \% \mathrm{KCl}$ FS at $20 \& 40 \mathrm{DAS}$ & 2.12 & 19.9 & 6.1 & 1685 \\
\hline $\mathrm{T}_{3}$ & $125 \% \mathrm{RDF}+1 \%$ Urea $+1 \% \mathrm{KCl}$ FS at $20 \& 40 \mathrm{DAS}$ & 2.24 & 21.3 & 6.4 & 1766 \\
\hline $\mathrm{T}_{4}$ & $75 \% \mathrm{RDF}+1 \%$ Urea $+1 \% \mathrm{KCl}+0.5 \% \mathrm{ZnSO}_{4}+0.5 \% \mathrm{FeSO}_{4} \mathrm{FS}$ at $20 \& 40 \mathrm{DAS}$ & 2.37 & 23.7 & 7.1 & 1881 \\
\hline $\mathrm{T}_{5}$ & $100 \% \mathrm{RDF}+1 \%$ Urea $+1 \% \mathrm{KCl}+0.5 \% \mathrm{ZnSO}_{4}+0.5 \% \mathrm{FeSO} 4 \mathrm{FS}$ at $20 \& 40 \mathrm{DAS}$ & 2.56 & 26.8 & 7.9 & 2078 \\
\hline $\mathrm{T}_{6}$ & $125 \% \mathrm{RDF}+1 \%$ Urea $+1 \% \mathrm{KCl}+0.5 \% \mathrm{ZnSO}_{4}+0.5 \% \mathrm{FeSO}_{4} \mathrm{FS}$ at $20 \& 40 \mathrm{DAS}$ & 2.68 & 27.3 & 8.2 & 2136 \\
\hline $\mathrm{T}_{7}$ & $75 \%$ RDF $+1 \%$ Polyfeed FS at $20 \& 40$ DAS & 1.86 & 18.1 & 5.5 & 1623 \\
\hline $\mathrm{T}_{8}$ & $100 \%$ RDF $+1 \%$ Polyfeed FS at $20 \& 40$ DAS & 2.08 & 19.3 & 5.7 & 1729 \\
\hline $\mathrm{T}_{9}$ & $125 \%$ RDF + $1 \%$ Polyfeed FS at $20 \& 40$ DAS & 2.19 & 20.5 & 5.9 & 1784 \\
\hline $\mathrm{T}_{10}$ & $75 \% \mathrm{RDF}+1 \%$ Polyfeed $+0.5 \% \mathrm{ZnSO}_{4}+0.5 \% \mathrm{FeSO}_{4} \mathrm{FS}$ at $20 \& 40 \mathrm{DAS}$ & 2.31 & 22.9 & 6.8 & 1849 \\
\hline $\mathrm{T}_{11}$ & $100 \% \mathrm{RDF}+1 \%$ Polyfeed $+0.5 \% \mathrm{ZnSO}_{4}+0.5 \% \mathrm{FeSO}_{4} \mathrm{FS}$ at $20 \& 40 \mathrm{DAS}$ & 2.42 & 23.5 & 7.1 & 1928 \\
\hline $\mathrm{T}_{12}$ & $125 \% \mathrm{RDF}+1 \%$ Polyfeed $+0.5 \% \mathrm{ZnSO}_{4}+0.5 \% \mathrm{FeSO}_{4} \mathrm{FS}$ at $20 \& 40 \mathrm{DAS}$ & 2.46 & 24.1 & 7.3 & 1962 \\
\hline $\mathrm{T}_{13}$ & Absolute Control & 1.72 & 14.7 & 4.7 & 1146 \\
\hline & SEd & 0.06 & 1.06 & 0.27 & 52 \\
\hline & $\mathrm{CD}(\mathrm{P}=0.05)$ & 0.13 & 2.2 & 0.56 & 107 \\
\hline
\end{tabular}

RDF - Recommended Dose of Fertilizers, FS - Foliar spray

\section{Earhead length and earhead girth $(\mathrm{cm})$}

Significantly maximum earhead length $(27.3 \mathrm{~cm})$ and girth $(8.2 \mathrm{~cm})$ registered with application of $125 \% \mathrm{RDF}+1 \%$ Urea $+1 \% \mathrm{KCl}+0.5 \% \mathrm{ZnSO}_{4}+0.5 \% \mathrm{FeSO}_{4}\left(\mathrm{~T}_{6}\right)$. It was statistically at par with $100 \% \mathrm{RDF}+1 \%$ Urea $+1 \% \mathrm{KCl}+$ $0.5 \% \mathrm{ZnSO}_{4}+0.5 \% \mathrm{FeSO}_{4}\left(\mathrm{~T}_{5}\right)$ which registered earhead length and girth of $26.8 \mathrm{~cm}$ and $7.9 \mathrm{~cm}$ respectively. The lowest earhead length and girth $(14.7 \mathrm{~cm}$ and $4.7 \mathrm{~cm})$ was observed with absolute control (Table 1). Application of increased levels and foliar spray of nutrients might have ensured prolonged availability of nutrients for earhead development than control treatment. This was on similarity with Potanna (2017) ${ }^{[8]}$ and Singh and Chauhan (2014) ${ }^{[15]}$.

\section{No. of grains earhead ${ }^{-1}$}

Number of grains earhead ${ }^{-1}$ was found significantly influenced by different fertility levels and foliar nutrients spray (Table 1). Significantly higher number of grains earhead $^{-1}$ (2136) was found with application of $125 \% \mathrm{RDF}+$ $1 \%$ Urea $+1 \% \mathrm{KCl}+0.5 \% \mathrm{ZnSO}_{4}+0.5 \% \mathrm{FeSO}_{4}\left(\mathrm{~T}_{6}\right)$ which was statistically on par with $100 \% \mathrm{RDF}+1 \%$ Urea $+1 \% \mathrm{KCl}$ $+0.5 \% \mathrm{ZnSO}_{4}+0.5 \% \mathrm{FeSO}_{4}\left(\mathrm{~T}_{5}\right)$ (2078). Absolute control had recorded minimum number of grains earhead ${ }^{-1}(1146)$. As reported by Chouhan et al., (2018) [2] and Ananthi and Parasuraman (2019) ${ }^{[1]}$, higher dose of potassium and foliar supplied nutrients might be the reason that improved the pollen germination by enhancing nutrient supply to flower parts which helped in high spikelet fertility and thus produced high number of fertile filled grains in earhead than control.

\section{Test weight}

In field investigation, test weight was significantly influenced 
by treatments applied (Table 2). Application of $125 \% \mathrm{RDF}+$ $1 \%$ Urea $+1 \% \mathrm{KCl}+0.5 \% \mathrm{ZnSO}_{4}+0.5 \% \mathrm{FeSO}_{4}\left(\mathrm{~T}_{6}\right)$ had produced significantly maximum test weight of $15.46 \mathrm{~g}$ which was statistically at par with $100 \% \mathrm{RDF}+1 \%$ Urea $+1 \% \mathrm{KCl}$ $+0.5 \% \mathrm{ZnSO}_{4}+0.5 \% \mathrm{FeSO}_{4}\left(\mathrm{~T}_{5}\right)(15.18 \mathrm{~g})$, while lower test weight of $10.27 \mathrm{~g}$ was recorded with absolute control. Improved test weight could be due to foliar application of urea which might have ensured nitrogen availability at later grain filling stages. Foliar applied nutrients might enhance the mobilization of photosynthates from source to sink and improved the sink accumulation capacity which resulted in increased grain weight as reported by Rahman et al., (2014) ${ }^{[9]}$, Naveenaa et al., (2018) ${ }^{[6]}$ and Kishor et al., (2017) ${ }^{[5]}$.

Table 2: Effect of fertilizer levels and foliar nutrition on Test weight, Grain and Straw yield of rainfed Pearl millet

\begin{tabular}{|c|c|c|c|c|}
\hline \multicolumn{2}{|r|}{ Treatments } & \begin{tabular}{|c|} 
Test weight \\
$(\mathrm{g})$
\end{tabular} & $\begin{array}{c}\text { Grain yield } \\
\left(\mathrm{kg} \mathrm{ha}^{-1}\right)\end{array}$ & $\begin{array}{c}\text { Straw yield } \\
\left(\mathrm{kg} \mathrm{ha}^{-1}\right)\end{array}$ \\
\hline $\mathrm{T}_{1}$ & $75 \% \mathrm{RDF}+1 \%$ Urea $+1 \% \mathrm{KCl} \mathrm{FS}$ at $20 \& 40 \mathrm{DAS}$ & 13.68 & 2092 & 3381 \\
\hline $\mathrm{T}_{2}$ & $100 \% \mathrm{RDF}+1 \%$ Urea $+1 \% \mathrm{KCl}$ FS at $20 \& 40 \mathrm{DAS}$ & 13.65 & 2206 & 3487 \\
\hline $\mathrm{T}_{3}$ & $125 \% \mathrm{RDF}+1 \%$ Urea $+1 \% \mathrm{KCl}$ FS at $20 \& 40 \mathrm{DAS}$ & 13.87 & 2314 & 3594 \\
\hline $\mathrm{T}_{4}$ & $75 \% \mathrm{RDF}+1 \%$ Urea $+1 \% \mathrm{KCl}+0.5 \% \mathrm{ZnSO}_{4}+0.5 \% \mathrm{FeSO}_{4} \mathrm{FS}$ at $20 \& 40 \mathrm{DAS}$ & 14.61 & 2435 & 3756 \\
\hline $\mathrm{T}_{5}$ & $100 \% \mathrm{RDF}+1 \%$ Urea $+1 \% \mathrm{KCl}+0.5 \% \mathrm{ZnSO}_{4}+0.5 \% \mathrm{FeSO}_{4} \mathrm{FS}$ at $20 \& 40 \mathrm{DAS}$ & 15.18 & 2627 & 4058 \\
\hline $\mathrm{T}_{6}$ & $125 \% \mathrm{RDF}+1 \%$ Urea $+1 \% \mathrm{KCl}+0.5 \% \mathrm{ZnSO}_{4}+0.5 \% \mathrm{FeSO}_{4} \mathrm{FS}$ at $20 \& 40 \mathrm{DAS}$ & 15.46 & 2692 & 4134 \\
\hline $\mathrm{T}_{7}$ & $75 \%$ RDF $+1 \%$ Polyfeed FS at $20 \& 40$ DAS & 13.52 & 2026 & 3356 \\
\hline $\mathrm{T}_{8}$ & $100 \%$ RDF $+1 \%$ Polyfeed FS at $20 \& 40$ DAS & 13.67 & 2138 & 3419 \\
\hline $\mathrm{T}_{9}$ & $125 \%$ RDF + $1 \%$ Polyfeed FS at $20 \& 40$ DAS & 13.69 & 2254 & 3521 \\
\hline $\mathrm{T}_{10}$ & $75 \%$ RDF $+1 \%$ Polyfeed $+0.5 \% \mathrm{ZnSO}_{4}+0.5 \% \mathrm{FeSO}_{4} \mathrm{FS}$ at $20 \& 40 \mathrm{DAS}$ & 14.18 & 2347 & 3639 \\
\hline $\mathrm{T}_{11}$ & $100 \% \mathrm{RDF}+1 \%$ Polyfeed $+0.5 \% \mathrm{ZnSO}_{4}+0.5 \% \mathrm{FeSO}_{4} \mathrm{FS}$ at $20 \& 40 \mathrm{DAS}$ & 14.46 & 2469 & 3802 \\
\hline $\mathrm{T}_{12}$ & $125 \% \mathrm{RDF}+1 \%$ Polyfeed $+0.5 \% \mathrm{ZnSO}_{4}+0.5 \% \mathrm{FeSO}_{4} \mathrm{FS}$ at $20 \& 40 \mathrm{DAS}$ & 14.65 & 2507 & 3870 \\
\hline $\mathrm{T}_{13}$ & Absolute Control & 10.27 & 1635 & 2914 \\
\hline & SEd & 0.22 & 54 & 72 \\
\hline & $\mathrm{CD}(\mathrm{P}=0.05)$ & 0.45 & 112 & 149 \\
\hline
\end{tabular}

\section{Effect on yield}

The grain yield and straw yield were also in similar trend as yield attributes. Yield of pearl millet was significantly influenced by different fertilizer levels and foliar nutrition treatments as presented in Table 2.

\section{Grain yield}

Significantly higher grain yield of $2692 \mathrm{~kg} \mathrm{ha}^{-1}$ was observed with application of $125 \% \mathrm{RDF}+1 \%$ Urea $+1 \% \mathrm{KCl}+0.5 \%$ $\mathrm{ZnSO}_{4}+0.5 \% \mathrm{FeSO}_{4}\left(\mathrm{~T}_{6}\right)$ (Table 2) than that of other treatments. It was statistically at par with $100 \% \mathrm{RDF}+1 \%$ $\mathrm{Urea}+1 \% \mathrm{KCl}+0.5 \% \mathrm{ZnSO}_{4}+0.5 \% \mathrm{FeSO}_{4}\left(\mathrm{~T}_{5}\right)(2627 \mathrm{~kg}$ $\left.\mathrm{ha}^{-1}\right)$. The lowest grain yield was recorded with absolute control $\left(1635 \mathrm{~kg} \mathrm{ha}^{-1}\right)$. Increase in grain yield over control might be due to combined application of high fertilizer dose and foliar nutrition spray which delayed the senescence and improved the photosynthetic efficiency. It had also facilitated the effective translocation of photosynthates and partitioning to different sink. Thus resulted in increased yield attributing characters and hence improved the grain yield of crop. Similar results were reported by Rundla and Bairwa (2018) ${ }^{[13]}$, Yadav and Choudhary (2012) ${ }^{[17]}$ and Reddy et al., (2018) ${ }^{[12]}$. Total rainfall from sowing to harvest of the crop recorded was $461.2 \mathrm{~mm}$ in 42 rainy days. This could have favoured the crop stand and better crop performance with higher dose of $125 \%$ of RDF under rainfed condition.

\section{Straw yield}

Straw yield was significantly influenced by application of different fertilizer levels and foliar nutrition spray (Table 2). Application of $125 \% \mathrm{RDF}+1 \%$ Urea $+1 \% \mathrm{KCl}+0.5 \%$ $\mathrm{ZnSO}_{4}+0.5 \% \mathrm{FeSO}_{4}\left(\mathrm{~T}_{6}\right)$ had recorded significantly higher straw yield of $4134 \mathrm{~kg} \mathrm{ha}^{-1}$ which was statistically at par with $100 \% \mathrm{RDF}+1 \%$ Urea $+1 \% \mathrm{KCl}+0.5 \% \mathrm{ZnSO}_{4}+0.5 \%$ $\mathrm{FeSO}_{4}\left(\mathrm{~T}_{5}\right)\left(4058 \mathrm{~kg} \mathrm{ha}^{-1}\right)$. Absolute control recorded lowest straw yield of $2914 \mathrm{~kg} \mathrm{ha}^{-1}$. Increase in straw yield might be due to profuse tillering and improved vegetative growth and growth parameters by the application of higher fertilizer doses at early stages. Foliar nutrition spray of urea, iron and zinc increased the straw content by ensuring better nutrient availability. This was on similar trend with Joshi et al., (2018) ${ }^{[4]}$, Rani et al., (2017) ${ }^{[10]}$ and Patel et al., (2019) ${ }^{[7]}$.

\section{Conclusion}

From the field experiment, it was concluded that significantly higher yield and yield attributing characters of rainfed pearl millet were observed with application of $125 \%$ RDF combined with foliar spraying of $1 \%$ Urea $+1 \% \mathrm{KCl}+0.5 \%$ $\mathrm{ZnSO}_{4}+0.5 \% \mathrm{FeSO}_{4}$ than other treatments studied.

\section{References}

1. Ananthi K, P Parasuraman. Response of micronutrients foliar spray on leaf area, leaf area index, TDMA and yield variation in Varagu under rainfed condition." Journal of Pharmacognosy and Phytochemistry 2019;2:32-34.

2. Chouhan Sudhanshu, Sita Ram Naga, Priyanka Bhadru, Deepak Kumar, Ajay Kumar, Aman Jaiswal. Effect of Bio-organic and Potassium on Yield attributes of Pearl millet Pennisetum glaucum (L.) R. Br. emend Stuntz." International Journal of Chemical Studies 2018;6(2):2038-2041.

3. Gomez Kwanchai A, Arturo A Gomez. Statistical procedures for agricultural research. John Wiley and Sons 1984.

4. Joshi Maitrik P, RM Pankhaniya, Nazir Khan Mohammadi. Response of pearl millet (Pennisetum glaucum L.) to levels and scheduling of nitrogen under south Gujarat condition. International Journal of Chemical Studies 2018;6(1):32-35.

5. Kishor Kaushal, MK Kaushik, Vinod Kumar Yadav, Pragya Gautam. Effect of fertility levels on Yield and Yield attribute of different Sorghum [Sorghum bicolor (L.) Moench] genotypes. Journal of Pharmacognosy and Phytochemistry 2017;6(4):541-543.

6. Naveenaa M, A Amaregouda, MK Meena, TC Suma, PH Kuchanur. Influence of foliar nutrition at different vegetative stages on growth and yield performance of 
maize (Zea mays L.). Journal of Pharmacognosy and Phytochemistry 2018;7(5):249-255.

7. Patel NI, BR Patel, CK Patel, Foram B Patel. Effect of foliar spray of nutrients at different growth stages on pearl millet under Dryland condition. International Journal of Chemical Studies 2019;7(5):5-9.

8. Potanna Arshewar Sunil. Effect of nitrogen and zinc on growth, yield and uptake of Pearl millet (Pennisetum glaucum L.)." Master of science, Agronomy, College of agriculture, Latur 2017.

9. Rahman MZ, MR Islam, MA Karim, MT Islam. "Response of wheat to foliar application of urea fertilizer. J Sylhet Agril. Univ. 2014;1(1):39-43.

10. Rani Y Sandhya, U Triveni, Patro Tssk, N Anuradha. Effect of nutrient management on yield and quality of finger millet (Eleusine coracana (L.) Gaertn). International Journal of Chemical Studies 2017;5(6):1211-1216.

11. Reddy AA, PP Rao, OP Yadav, IP Singh, NJ Ardeshna, KK Kundu, et al. Prospects for kharif (Rainy Season) and Summer Pearl Millet in Western India. Working Paper Series no. 36, International Crops Research Institute for the Semi-Arid Tropics. Patancheru 502 324, Andhra Pradesh, India 2013, 24.

12. Reddy BH, AV Bulbule, PN Gajbhiye, DS Patil. Effect of Foliar Application of Plant Nutrients on Growth and Yield of Finger Millet. International Journal of Current Microbiology and Applied Sciences 2018;7(3):22032209.

13. Rundla Surgyan, RC Bairwa. Response of Foliar Supplementation of N, P and K Fertilizers on Yield and Economics of Pearl Millet. International Journal of Current Microbiology and Applied Sciences 2018;7(4):1203-1209.

14. Singh Lakhan, PK Sharma, M Jajoria, P Deewan, R Verma. Effect of Phosphorus and Zinc Application on Growth and Yield Attributes of Pearl millet (Pennisetum glaucum L.) under Rainfed Condition." Journal of Pharmacognosy and Phytochemistry 2017;6(1):388-391.

15. Singh Sant Bahadur, SK Chauhan. Productivity and Economics of Pearl Millet as Influenced by Integrated Nutrient Management. Annals of Plant and Soil Research 2014;16(4):356-358.

16. Suresh Gurrala, G Guru, Subbalakshmi Lokanadan. "Effect of Nutrient Levels and Plant Growth Regulators on Growth Parameters of Pearl Millet. International Journal of Pure and Applied Bioscience 2018;6(3):271277.

17. Yadav LR, GL Choudhary. Effect of fertility levels and foliar nutrition on profitability, nutrient content and uptake of cowpea [Vigna unguiculata (L.) walp]." Legume Research 2012;35(3):258-260. 